This manuscript is contextually identical with the following published paper:

Lukács, Á ; Kókai, Zs ; Török, P ; Bácsi, I ; Borics, G ; Várbíró, G ; T-Krasznai, E ;

Tóthmérész, B ; B-Béres, V (2018) Colonisation processes in benthic algal communities are well reflected by functional groups. - HYDROBIOLOGIA $823 \mathrm{pp}$. 231-245.

The original published PDF available in this website:

https://doi.org/10.1007/s10750-018-3711-z

\title{
Colonisation processes in benthic algal communities are well reflected by functional
}

groups

Áron Lukács ${ }^{1}$, Zsuzsanna Kókai ${ }^{2}$, Péter Török ${ }^{3}$, István Bácsi ${ }^{1}$, Gábor Borics ${ }^{4,5}$, Gábor

Várbíró $^{4,5}$, Enikő T-Krasznai ${ }^{6}$, Béla Tóthmérész ${ }^{2,7}$, Viktória B-Béres $^{3,5^{*}}$

${ }^{1}$ University of Debrecen, Department of Hydrobiology, H-4032 Debrecen Egyetem square 1,

Hungary

${ }^{2}$ University of Debrecen, Department of Ecology, H-4032 Debrecen, Egyetem square 1,

Hungary

${ }^{3}$ MTA-DE Lendület Functional and Restoration Ecology Research Group, H-4032 Debrecen

Egyetem square 1, Hungary

${ }^{4}$ Hungarian Academy of Sciences, Centre for Ecological Research, Danube Research Institute, Department of Tisza Research, H-4026 Debrecen, Bem square 1, Hungary

${ }^{5}$ MTA Centre for Ecological Research, GINOP Sustainable Ecosystems Group, H-8237

Tihany, Klebelsberg Kuno u. 3, Hungary

${ }^{6}$ Hajdú-Bihar County Government Office, Department of Environment and Conservation,

Environmental Laboratory, H-4025 Debrecen, 16 Hatvan street, Hungary

${ }^{7}$ MTA-DE Biodiversity and Ecosystem Services Research Group, H-4032 Debrecen, Egyetem square 1, Hungary

*corresponding author: Viktória B-Béres, e-mail: beres.viktoria@gmail.com 


\begin{abstract}
Single trait analyses are used to select the most appropriate species characteristics for an effective indication of changes in multiple stressors, but they are robust to detect fine-scale functional changes in biofilms. The combination of single traits may appropriately reflect ecological properties of changing benthic assemblages. We studied colonisation processes of benthic algal assemblages focusing on the changes in trait composition using life-forms, type of attachments, cell size and mobility as single traits in a small lowland stream. We tested the descriptive power of single trait groups (STGs) and also combined trait groups (CTGs). We assumed, that STGs would be significantly affected by environmental factors, but compositional changes in biofilms would be described more easily by using CTGs rather than STGs. Our hypotheses were confirmed by the results. While some STGs correlated positively to environmental factors indicating disturbances, others correlated to environmental factors indicating the stable conditions. The fast settlement of large sized groups was also relevant determining the compositional changes in the studied benthic community. Despite the strong correlation between STGs and environmental variables, CTGs analyses revealed important functional relations in the ecosystem, since CTGs display more sophisticated functional features of the organisms, which may provide more realistic responses.
\end{abstract}

Key words: combined trait groups, single traits, benthic algal communities, functional processes, colonisation, watercourses 


\section{Introduction}

The freshwater phytobenthos consists of various algal assemblages, which have a crucial role both in the food web and in oxygen production of lotic ecosystems (Lange at al., 2016). Despite its high-level taxonomic diversity, diatoms are mostly used as the only algal proxy to assess ecological processes in rivers (Kelly, 2012; Tapolczai et al., 2016; Brabcova et al., 2017). It means that important characteristics of the ecosystem functionality in benthic assemblages still remain unrevealed, if qualitative and quantitative changes of non-diatoms are not considered (Kelly, 2012; DeNicola \& Martin, 2014; Tapolczai et al., 2016).

Even though functional approaches in ecological assessment of benthic assemblages started only recently, their application in evaluating ecological processes in freshwater ecosystems is beyond dispute (Tapolczai et al., 2016). The recently used functional classification of the phytobenthos are based either on diatoms (guilds - Passy, 2007; combined eco-morphological functional groups - B-Béres et al., 2016, 2017), or on both diatom and non-diatom algal groups (combined CSR strategy classification of Law et al., 2014; trait based conceptual framework - Lange et al., 2016). These classifications rely on ecologically and functionally relevant traits like cell size/volume; maximum linear dimension; type of attachment on the substrate; mobility; ability of nitrogen-fixation; likeliness of spore formation; or reproduction type.

Although a coherent benthic life form classification was developed for diatoms (Rimet \& Bouchez, 2012 based on Round et al., 1990; Table 1), the use of this classification for nondiatoms is also feasible (Law et al., 2014; Lange et al., 2016). While some studies reported a strong relationship between life forms and environmental factors (Berthon et al., 2011; Lange 
et al., 2016, Marcel et al., 2017), others have not found any relationship between these variables (Law et al., 2014). However, Law et al. (2014) demonstrated that a higher functional resolution can be achieved by combining life forms with other traits (maximum linear dimension, surface area to volume ratio), and the created groups have strong significant relation to environmental factors.

In general, the type of attachment is a strong indicator of water flow conditions. But there is no clear consensus on whether or not there is a direct positive relationship between the strength of water flow and attachment (Passy, 2007; Gottschalk \& Kahlert, 2012; Lange et al., 2016). Actually, it seems that other circumstances (stability of flow conditions, nutrient content) also enable to change the effects of water flow as a stress factor on the type of attachment (Lange et al., 2016).

One of the most frequently used traits is the cell size. Studies demonstrated that different sized taxa have different sensitivity to the changes in physical and chemical environment (Plenkovic-Moraj et al., 2008; Finkel et al., 2009; Lange et al., 2016). Nowadays, the most often used cell size classification system was proposed by Berthon et al. (2011), that contains five cell size classes (Table 1). The use of these classes in the assessment of the ecological status of watercourses either alone or together with other traits was validated by former researches (Berthon et al., 2011; Kókai et al., 2015; B-Béres et al., 2016, 2017).

Analyses using mobility traits could also be useful to display many changes in the environment (Berthon et al., 2011; B-Béres et al., 2014; Lengyel et al., 2015; Lange et al., 2016). Mobile taxa are able to change their position in a direct and active way. They benefit from their ability to choose the most appropriate microhabitats (Berthon et al., 2011; Stenger- 
Kovács et al., 2013; B-Béres et al., 2014, 2016, 2017; Lange et al., 2016). The movement can be fast (like in the case of flagellated non-diatoms, or nitzschoid and symmetrical naviculoid diatoms), or slow (e.g. monoraphid diatoms). While the mobility of diatom taxa is closely related to the raphe of the diatom frustule, movement of non-diatom taxa is usually supported by the presence of one or more flagella. The combination of the mobility trait with other traits can provide a higher functional resolution. In a former study, we demonstrated that using this combination functionally relevant relationship between algae and the environment could be detected (e.g. strong positive relation between the increasing dominance of small, motile taxa in assemblages and the decrease of water depth), which remained hidden in single trait analyses (B-Béres et al., 2016).

In this study, we investigated the colonization processes of benthic algae in a small, nonintermittent lowland stream in 2014 (from15.03.2014 to 06.06.2014). During this period, the precipitation was low (totally $94 \mathrm{~mm}$ ) and its distribution was uneven (Fig. 1), thus the stream drought out in June. We analyzed the changes in trait composition of algal assemblages such as life-forms, attachment to substrate, cell size and mobility. To understand the functional mechanisms in the phytobenthos, we analyzed the correlations of single trait groups (STGs) based on sole traits, and trait combination groups (CTGs) as defined by combined all traits together with the changes of environmental factors. We used the following hypotheses which are directly linked to the referred literature:

(i) The proportion of colonial and filamentous groups will be high at the beginning of the colonization processes (Ács \& Kiss, 1993). In contrast, the proportion of unicellular taxa will increase with the increasing environmental disturbances (rainy and arid periods during the timeframe of the study; B-Béres et al., 2016). 
(ii) Weakly attached group will be characteristic under stable water flow conditions (Lange et al., 2016), while strongly attached group will indicate the drastic changes in water flow (B-Béres et al., 2016).

(iii) Opposite changes in the proportion of small and large sized groups are hypothesised (B-Béres et al., 2016). Due to the increasing environmental disturbances, proportion of small sized taxa will increase.

(iv) With the increasing disturbances and also with the risk of the drying up of the studied stream, the proportion of mobile groups will also increase (B-Béres et al., 2016; Lange et al., 2016). In contrast, opposite changes in the proportion of fast and slow moving groups are hypothesised due to their different stress tolerances (Passy \& Larson, 2011).

(v) Application of CTGs will contribute to describe the observed changing environmental conditions in a more sensitive and reliable way than using solely STGs (B-Béres et al., 2016).

\section{Materials and Methods}

\section{Sampling setup and measurements}

Samples were collected on the stream bed of Tócó stream at Debrecen-Józsa in Hungary $\left(47^{\circ} 36^{\prime} 27.3^{\prime \prime} \mathrm{N} 21^{\circ} 34^{\prime} 29.0^{\prime \prime E}\right)$. Tócó stream is a small-sized (catchment area: $10-100 \mathrm{~km}^{2}$; total length: $26 \mathrm{~km})$, low altitude $(<200 \mathrm{~m})$ watercourse with fine sediment. Its general physical and chemical conditions are good except for its enhanced nitrate and phosphate contents. At the selected sampling site no organic pollution characterised the stream (2nd River Basin Management Plans; web1). 
The colonization process was studied from 15.03.2014 to 06.06.2014 (thereafter the stream dried up). The timetable of the sampling was planned according to Ács et al. 2000, but it was modified because of the timeframe of the study: Samples were collected hourly in the first 9 hours; daily in the first week; twice a week until the $35^{\text {th }}$ day; and weekly at the second part of the study (B-Béres et al., 2016). Altogether 12 environmental factors were measured (Appendix 1). Conductivity (COND $\left.-\mu \mathrm{S} \mathrm{cm}^{-1}\right)$, oxidation-reduction potential $(\mathrm{ORP}-\mathrm{mV})$, $\mathrm{pH}$, dissolved oxygen concentration ( $\left.\mathrm{DO}-\mathrm{mg} \mathrm{L}^{-1}\right)$, oxygen saturation $(\mathrm{OS}-\%)$ and water temperature $\left(\mathrm{T},{ }^{\circ} \mathrm{C}\right)$ were measured by a portable-multiparameter digital meter (HQ30d) in the field. Water depth (WD, cm) was measured by a measuring tape, water velocity $\left(\mathrm{WV}-\mathrm{m} \mathrm{s}^{-1}\right)$ was measured by a SonTek FlowTracker Handheld-ADV (USA). Water samples were kept at $4{ }^{\circ} \mathrm{C}$ in a cooler bag during transportation to the laboratory for further analyses. Nitrite, nitrate, ammonium and soluble reactive phosphorus were measured by spectrophotometric methods $\left(\mathrm{NO}_{2}{ }^{-}, \mathrm{NO}_{3}{ }^{-}, \mathrm{NH}_{4}{ }^{+}\right.$and $\mathrm{PO}_{4}{ }^{3-}, \mathrm{mg} \mathrm{L}^{-1}$; MSZ ISO 7150-1:1992; MSZ EN ISO 6878:2004; MSZ 1484-13:2009).

\section{Sample collection and microscopic analyses}

Emergent macrophytes (Phragmites australis, Typha spp.) are the characteristic and usually the only relevant substrates in Tócó stream. Beyond them, only leaves, branches and some macroscopic invertebrates (freshwater bivalves and snails) are present as potential surfaces in the stream bed. Although development of more diverse assemblages are expected on natural substrates, artificial ones have many advantages, like the well-controlled duration of exposure, the measurable area or their easy handling (Barbiero, 2000). Thus, semi-artificial wooden slides were chosen as substrates in this study. Chemical composition of these wooden slides is more similar to that of macrophytes, than any other types of artificial substrates (e.g. 
glass, plastic, granite, etc.). Wooden slides contain, components like cellulose, lignin, polysaccharides, etc. (Papp, 2010) in only slightly different quantities than natural living or dead plant material. Therefore, the composition of assemblages developing on these slides is considered to be similar to that of natural biofilms in Tócó stream. The dimensions of the wooden slides were the following: $6 \mathrm{~cm}$ in length; $2 \mathrm{~cm}$ in width; and $0.5 \mathrm{~cm}$ in height; the surface area of each was $32 \mathrm{~cm}^{2}$. A total of 36 pieces of wooden slides were bound to a chain. Three chains of slides were put into the stream bed at the sampling site. Three slides were collected at each sampling date (one per chain). Because the stream dried up, only 31 pieces of wooden slides per chain, i.e. 93 slides in total, were collected during the studied period. The slides were preserved in Lugol's solution. The biofilm was removed from the slides by toothbrushes in the laboratory. The samples collected at the same time were processed separately, i.e. a total of 93 samples were analysed by microscope. The counting was performed according to the CEN 15204 standard and to the Hungarian guidance on sampling, analysis and counting standards for phytoplankton (Borics \& Kiss, 2015). Samples were filled into sedimentation chambers ( $1 \mathrm{ml}$ final volume). After the settling time (at least 4 hours), Leica DMIL inverse microscope with 400-fold magnification was used for identification of algal taxa. At least 400 living algal units (with chloroplast) were identified per sample. An algal unit can be a unicellular individual (actually a single cell), a colony or a filament. We used Krammer and Lange-Bertalot (1997a,b; 2004a,b) for diatom identification and Ettl (1983), Kadlubowska (1984), Komárek and Anagnostidis (1998, 2005), Németh (1997a,b), Schmidt and Fehér (1998, 1999, 2001), Grigorszky et al. (1999), Uherkovich et al. (1995) and Javornický (2003) for soft algae (non-diatoms) identification.

\section{Data processing and analyses}


Pooled relative abundances of each taxa ( 3 samples pooled in each days) were used for further analyses. Similarly to the traditional benthic diatom analyses, relative abundances were not weighted by the biovolume of taxa.

A total of 68 taxa were identified in samples and they were classified into different trait categories (see below).

Classifying algal taxa into three life form groups (unicellular, colonial and filamentous) was done according to Rimet and Bouchez (2012) and Lange et al. (2016) (Table 1; Appendix 2). Three types of attachment were differentiated (weakly, moderately and strongly attached) according to Lange et al. (2016). Diatom taxa were assigned to five cell size classes according to Berthon et al. (2011) and complemented by size data of non-diatom taxa according to the Hungarian National Phytoplankton Database (Table 1; Appendix 2). These databases contain average biovolume data of algal units. Three mobility groups were differed from each other (non-mobile, fast moving and slow moving). After some modification according to Passy and Larson (2011), mobility classification of diatom taxa was done according to Rimet and Bouchez (2012) complemented by data on non-diatoms (Table 1; Appendix 2). The fast moving group contains nitzschoid and symmetrical naviculoid diatoms, and flagellated nondiatoms. All monoraphid diatoms belong to the slow moving group.

Based on the combination of single traits, taxa were classified into CTGs (3 life form groups $\times 3$ attachment group $\times 5$ cell size groups $\times 3$ mobility groups - without the not existing options of the different sized non-mobile flagellated and mobile filamentous groups; Table 2; Appendix 2). 
To analyse the relationship between environmental factors and the samples, and to select crucial abiotic factors, principal component analyses (PCA) were calculated using CANOCO 5.0 software package (ter Braak \& Šmilauer, 2002). To analyze the relationship between time (in days), environmental factors and the single traits (life forms, types of attachment, cell size classes, mobility) or combined groups of benthic algal assemblages ( CTGs) redundancy analyses (RDA) were used applying CANOCO 5.0 software package (ter Braak \& Šmilauer, 2002), where environmental factors were added by the method of weighted averaging (ter Braak \& Šmilauer, 2002). Monte Carlo permutation test (499 permutations) was used to decide whether the detected pattern is significantly different from the random pattern.

\section{Definition of disturbances}

Here, environmental disturbances were defined as significant decrease in water depth caused by rainy and arid periods, which appeared from the 3-3.5 weeks (Fig. 1). Therefore, a negative correlation of STGs or CTGs with water depth and velocity, and their positive correlation with time are indicating their tolerance against disturbed conditions caused by the stream drying.

\section{Results}

\section{Changes in environmental factors}

The principal component analyses (PCA) performed with altogether 13 physical and chemical factors and the time explained $96.58 \%$ of the data variability in the first two axes. All factors including also the time showed high (more, than $45 \%$ ) correlations with the first axis. 
Considering this result, the general physical and chemical conditions of the stream, and the stream drying (Fig. 1), six factors (water depth, water velocity, nitrate, soluble reactive phosphorus, water temperature and time) were performed by redundancy analyses in further analyses of the relationship between environmental factors and STGs or CTGs,

\section{Changes in STGs during colonization}

Significant correlation was found between the environmental factors and STGs based on the results of RDA (Monte-Carlo permutation test: 499 permutations; $p=0.002$ for all axes; Table $3 \mathrm{~A})$. The explained variations were $62.48 \%$ and $13.94 \%$ along the first and the second axes, respectively.

The life form groups were clearly separated along the environmental factors (Fig. 2). While unicellular taxa correlated positively with temperature and time and negatively to water depth and velocity other groups (colonial and flagellate groups) showed an opposite trend (Fig. 2). These latter life form groups however, showed a positive correlation with nitrate (colonial group), or water depth (filamentous group).

There was a clear separation of the three attachment groups along the environmental gradients

(Fig. 2). The strongly attached group showed clear positive correlation with time. In contrast, the moderately attached group positively correlated with nitrate, while the weakly attached group showed strong negative correlation with time and phosphate.

The size classes clearly separated along the environmental variables (Fig. 2). While the smallest and the medium sized groups (S1 and S3 size classes) obviously correlated with time, the other relatively small sized group (S2 size class) correlated positively with nitrate and negatively with time. There was strong and conspicuous correlation between large sized groups (S4 and S5 size classes) and water depth and current velocity. 
The relations between mobility groups and environmental factors clearly differed from each other (Fig. 2). While there was a strong negative correlation between the non-mobile group and time, the slow moving group correlated positively to time. The fast moving group, in turn, correlated negatively to phosphate, and positively to water velocity.

\section{Changes in CTGs during colonization}

Significant correlation was found between CTGs and environmental factors (Monte-Carlo permutation test: 499 permutations; $p=0.002$ for all axes; Table 3B). The explained variations were $36.91 \%$ and $5.81 \%$ along the first and the second axes, respectively. There were some relevant differences between STGs and CTGs analyses (Figs. 2, 3) summarized in Table 4. While the colonial and moderately attached STGs correlated positively to nitrate (Fig. 2), the S3, S4 and S5 sized, slow moving, colonial and weakly attached CTGs showed positive correlation with time (S3SMCMa), or with water depth and current velocity (S4NMCMa, S5NMCMa) (Fig. 3). While there was positive correlation between nitrate and the medium size, non-mobile, filamentous and moderately attached groups (S3NMFMa - Fig. 3), the S3 size classes correlated positively to time (Fig. 2). In contrast to the strong negative correlation between the nutrients and the fast moving STG (Fig. 2), the different sized, fast moving, unicellular and weakly attached CTGs showed positive correlation to phosphate (S3FNUWa), to nitrate (S2FMUWa), or to water depth and velocity (S4 and S5FMUWa) (Fig. 3).

\section{Discussion}

Recent studies demonstrated that both single traits and functional groups of benthic diatoms or other benthic algal assemblages may be useful indicators of environmental changes in 
watercourses (Berthon et al., 2011; Stenger-Kovács et al., 2013; Kókai et al., 2015; B-Béres et al., 2014, 2016, 2017; Lange et al., 2016; Marcel et al., 2017). Single traits or functional groups alone could indicate some physical and chemical changes in water courses (Kókai et al., 2015; Lengyel et al., 2015). Our results are in line with these previous reports, stressing the usefulness of trait-based approaches.

Life forms are powerful morphological traits that show strong relation to physical disturbances and resource utilization (Berthon et al., 2011; Lange et al., 2016; Marcel et al. 2017). In this study, we hypothesised opposite change in the proportion of unicellular and colonial and filamentous groups. The results confirmed this hypothesis (Fig. 2). Only the unicellular group correlated negatively to water depth (Fig. 2). The decrease of water depth indicated the drying up of Tócó stream after the fifth week. This environmental phenomenon resulted the essential restructuring of benthic assemblages. Unicellular taxa have a great ability to colonize the newly formed habitats during stream drying or water abstraction (Lange et al., 2016). The colonial group showed strong negative correlation to water temperature and time, while this group related positively to nitrate (Fig.2). Seemingly this result contradicted the present knowledge on colonial taxa, namely: colonial taxa are usually abundant in mature biofilms under low nutrient content and physically undisturbed conditions (Berthon et al., 2011; Stenger-Kovács et al., 2013; Law et al., 2014; Marcel et al., 2017). To resolve these contradictions, both the importance of breakaway of certain taxa (including colonial taxa) from the 'original' biofilm of Tócó stream at the beginning of examination and their fast settlement has to be emphasized. Stream drying had a strong negative impact on the filamentous group (Fig. 2), which correlated negatively with time but positively with water depth (Fig. 2). Lange et al. (2016) reported also that water abstraction and drying up of streams contributed to decrease of filamentous taxa in contrast to unicellular ones. 
In general, water flow conditions strongly influence the attachment types. As the first approach, strength of attachment is increased by increasing water flow (Passy, 2007; Gottschalk \& Kahlert, 2012). But Lange et al. (2016) highlighted that other circumstances can change the relation between water flow and attachment types. Thus, we hypothesised that type of attachment will be mainly affected by stability of water flow and water depth conditions. The results confirmed this hypothesis (Fig. 2). Weakly attached group was characteristic under stable water flow and water depth conditions at the beginning of colonisation. In contrast, the increasing risk of the drying up of the stream was clearly indicated by strongly attached group.

Cell size of taxa primarily affects to their settlement and also their spreading. Large size of algae makes them prone to settling (Ács \& Kiss, 1993). In contrast, small size enables the spread of the cells due to their slower settling. Furthermore, small sized taxa are able to live under highly disturbed circumstances (Stenger-Kovács et al., 2013; B-Béres et al., 2014, 2016; Kókai et al., 2015). Thus, increase in the proportion of small sized groups was hypothesised with the increasing environmental disturbances. The results supported this hypothesis (Fig. 2). Small and medium sized groups (except S2 size class) indicated the drastic decrease in water depth. In contrast, large sized groups (S4 and S5 size classes) negatively connected to colonisation time. These two phenomena clearly stressed that colonisation success depends primarily on the initial conditions of the ecosystem. While large size ensures advantages in the colonisation processes during stable conditions rapidly changing circumstances favour colonisation success of small sized taxa.

Mobility is one of the most powerful traits to avoid unfavoured habitats and to choose the most appropriate circumstances for the populations (Passy, 2007). In this study, increase of mobile groups with the increasing disturbances was hypothesised. This hypothesis was confirmed by the results (Fig. 2). While non-mobile group did not correlate positively to 
factors indicating disturbances, the slow moving group clearly indicated the varying flow regime of the stream. The elements of the slow moving group can colonize successfully the empty niches and their dominance indicates physical disturbances (B-Béres et al., 2016; Marcel et al., 2017). It is important to emphasise, that the speed of movement can also be important in stressing the degree of disturbances. Because stress tolerances of fast and slow moving groups are different (Passy \& Larson, 2011), we hypothesised opposite changes of these groups. The slow moving group correlated positively with time (Fig. 2). In contrast, the fast moving group did not show clear relation to disturbances (neither to low nor to high water flow conditions). Based on these obvious ecological differences between these groups, we propose to separate them from each other in the further studies. This phenomenon also draws attention to the possibility that combining single traits could lead to a better description of compositional changes in phytobenthos.

As it was detailed above, application of STGs is an effective way to highlight relevant relationships between single trait structure in assemblages and environmental factors. However, we hypothesised that the influence of the observed environmental changes on the composition of benthic assemblages will be described in a more sensitive and reliable way by using CTGs rather than STGs solely. Our results confirmed this hypothesis, the enhanced descriptive power of CTGs provided more realistic responses.

The positive correlation of the medium sized, slow moving, colonial and moderately attached (S3SMCMa) group to time and its negative correlation to nitrate clearly differed from the trends observed in the case of the colonial and the moderately attached groups, which related positively to nitrate (Figs. 2, 3). Former research showed significant correlation between the medium sized group and the stream drying (Kókai et al., 2015). Thus, the strong positive correlation of S3SMCMa group to time, i.e. the stream drying was probably supported by the size character of this CTG. But it is important to emphasize, that this CTG can be 
characterised by taxa which are able to produce extracellular enzymes (e.g. Encyonema sp.; Appendix 2). This ability offers advantages to these taxa in nutrient poor environment (Tapolczai et al., 2016; B-Béres et al., 2017). Further laboratory and field studies are needed to prove the general relevance of this feature in this group. In addition, the large sized, nonmobile, colonial and moderately attached (S4NMCMa, S5NMCMa) groups also related differently to environmental factors than the colonial and the moderately attached groups (positive correlation to water depth and velocity; Fig. 3, and positive correlation to nitrate; Fig. 2, respectively). The importance of large size in the early appearance of taxa was previously stressed by Ács and Kiss (1993) and B-Béres et al. (2016). Thus, we assume that the observed strong positive correlations between water depth and velocity and S4NMCMa and S5NMCMa groups were primarily due to the large size character of these CTGs. This feature contributed to the fast settlement of taxa belonging to these groups (e.g. Meridion circulare - S4NMCMa; Ulnaria ulna - S5NMCMa; Appendix 2).

The medium sized, non-mobile, filamentous and moderately attached group (S3NMFMa containing taxa like Klebsormidium sp.) showed different relation to environmental factors than S3 size class alone (Table 4). While S3NMFMa correlated positively to nitrate, water depth and velocity (Fig. 3) and negatively to time, the S3 group correlated positively to time (Fig. 2). As it was mentioned above, S3 group seemed to indicate stream drying in this study. Thus, we assume that the strong relation of S3NMFMa to the factors indicating stable conditions was primarily due to their filamentous and non-mobile characteristics. Since dominance of the drifting filamentous group in assemblages was usually negatively impacted by drying up of streams, but the more stable conditions together with enhanced nitrogen concentration contributed to increase of filamentous taxa in the waters (Lange et al., 2016).

Mobility of algae offers them the possibility to avoid the non-appropriate microhabitats (Passy, 2007). Although obvious positive correlation was found between slow moving group 
and time, the fast moving group had no relation to factors indicating undisturbed environment. This unexpected phenomenon becomes clear after the combination of this group with other traits (Fig. 3). The large sized, fast moving, unicellular and weakly attached groups (S4FMUWa and S5FMUWa) clearly indicated the increase of WD and WV and also negatively correlated with time. The strong negative correlation between S4FMUWa and S5FMUWa groups and time was due to the large size of taxa belonging to these CTGs (e.g. Surirella brebissonii - S5FMUWa; Surirella sp. - S4FMUWa; Appendix 2). These taxa settled down fast at the beginning of colonisation. Furthermore, the smaller sized, fast moving, unicellular and weakly attached groups (S2FMUWa and S3FMUWa) correlated positively to nutrients. This positive correlation was due to the presence of flagellated taxa (small sized cryptophytes; Appendix 2) in these groups. Flagellated taxa are frequently occurring planktonic elements in watercourses with high nutrient content (Abonyi et al., 2014). Additionally, it has to be emphasized, that there is no consensus as to whether positive or negative correlations are between the fast moving groups and nutrient supply. While some researches provided the high benefit of active mobility under nutrient rich conditions (Passy, 2007; Berthon et al., 2011; Stenger-Kovács et al., 2013; B-Béres et al., 2014, 2016, 2017), others found negative correlation between them (Lange et al., 2016). Our results suggested, that other features like cell size, or the type of movement (with flagella, or by gliding) significantly influenced this relationship.

The increasing anthropogenic and natural impacts on watercourses require ecologically welljustified results for effective achievement and accomplishment of biodiversity conservation strategies and water quality targets. Our results suggested that relations between environmental conditions and benthic assemblages can be described in a more reliable way by using combination trait groups than the traits solely. But it is important to emphasize that further studies are needed to select the effective trait combinations indicating real responses in 
different environments (e.g. different trophic conditions or physical disturbances, typological differences, etc.).

\section{Conclusions}

Here, temporal changes of benthic algal STGs and CTGs were studied. We supposed, that even STGs react well to environmental factors, relative abundance changes in phytobenthos can be described more easily and effectively by using CTGs rather than STGs. Our results confirmed these hypotheses. Unexpected and significant changes in multiple stressors basically defined not only the trait composition of benthic assemblages but also the process of colonization. However, our results pointed out that under the observed environmental conditions the description of these compositional changes in assemblages was easier by applying CTGs than using STGs. It was due to the descriptive power of CTGs, since CTGs take into account many functional features of the organisms, which may enhance the knowledge of the system functioning and may provide more realistic responses. Furthermore, the STGs were determined by the ecological requirements of taxa with high abundances (5$25 \%$ ) in the given STG. But the fine scale system (CTGs) enables highlighting the compositional changes in biofilm based not only on the abundant taxa but the others also. Although, the main function of assemblages is determined by dominant species the other taxa with lower abundance can also play a significant role in the ecosystem. Thus, by ignoring them from analysis, important relations can remain hidden.

It is important to stress that further laboratory and field studies are needed to prove the general relevance of some traits (e.g. tube-formation, mobility with flagella or by gliding, etc.) and to select from them the ecologically meaningful trait combinations indicating real responses in different environments. But thereafter, CTGs-analyses could be applied (i) to 
cover the habitat diversity in watercourses; (ii) in studies of direct ecological status assessment as part of newly created indices and (iii) to indicate significant changes in the functional structure of biofilms.

\section{Acknowledgements}

The authors are thankful for the contributions of the anonymous reviewers and for the support of Internal Research Project of the University of Debrecen (Bácsi I.), Hungarian Scientific Research Found (K 116639 - B. Tóthmérész and NKFIH K 119225 - P. Török) and the National Research, Development and Innovation Office (GINOP-2.3.2-15-2016-00019).

\section{References}

Abonyi, A., M. Leitão, I. Stanković, G. Borics, G. Várbíró \& J. Padisák, 2014. A large river (River Loire, France) survey to compare phytoplankton functional approaches: Do they display river zones in similar ways? Ecological Indicators 46: 11-22.

Ács, É. \& K. T. Kiss, 1993. Colonization process of diatoms on artificial substrate in the River Danube near Budapest (Hungary). Hydrobiologia 269/270: 307-315.

Ács, É., K. T. Kiss, K. Szabó \& J. Makk, 2000. Short-term colonisation sequence of periphyton on glass slides in a large river (River Danube, near Budapest). Algological Studies 100: 135-156.

Barbiero, R. P., 2000. A multi-lake comparison of epilithic diatom communities on natural and artificial substrates. Hydrobiologia 438: 157-170. 
B-Béres, V., P. Török, Zs. Kókai, E. T-Krasznai, B. Tóthmérész \& I. Bácsi, 2014. Ecological diatom guilds are useful but not sensitive enough as indicators of extremely changing water regimes. Hydrobiologia 738: 191-204.

B-Béres, V., Á. Lukács, P. Török, Zs. Kókai, Z. Novák, E. T-Krasznai, B. Tóthmérész \& I. Bácsi, 2016. Combined eco-morphological functional groups are reliable indicators of colonisation processes of benthic diatom assemblages in a lowland stream. Ecological Indicators 64: 31-38.

B-Béres, V., P. Török, Zs. Kókai, Á. Lukács, E. T-Krasznai, B. Tóthmérész \& I. Bácsi, 2017. Ecological background of diatom functional groups: Comparability of classification systems. Ecological Indicators 82: 183-188.

Berthon, V., A. Bouchez \& F. Rimet, 2011. Using diatom lifeforms and ecological guilds to assess organic pollution and trophic level in rivers: a case study of rivers in south eastern France. Hydrobiologia 673: 259-271.

Borics, G. \& K. T. Kiss, 2015. Módszertani útmutató a Fitoplakton élőlénycsoport VKI szerinti gyűjtéséhez és feldolgozásához. pp. 19. (in Hungarian).

Brabcova, B., P. Marvan, L. Opatrilova, K. Brabec, M. Frankova \& J. Hetesa, 2017. Diatoms in water quality assessment: to count or not to count them? Hydrobiologia 795: 113127.

CEN 15204:2006, 2006. Water quality. Guidance standard on the enumeration of phytoplankton using inverted microscopy (Utermöhl technique).

DeNicola, D. M. \& M. Kelly, 2014. Role of periphyton in ecological assessment of lakes. Freshwater Science 33: 619-638.

Ettl, H., 1983. Süßwasserflora von Mitteleuropa, Volume 9: Chlorophyta I: Phytomonadina. Gustav Fischer Verlag, Jena. 
Finkel, Z. V., C. J. Vaillancourt, A. J. Irwin, E. D. Reavie \& J. P. Smol, 2009. Environmental control of diatom community size structure varies across aquatic ecosystems. Proceedings of the Royal Society B 276: 1627-1634.

Gottschalk, S. \& M. Kahlert, 2012. Shifts in taxonomical and guild composition of littoral diatom assemblages along environmental gradients. Hydrobiologia 694: 41-56.

Grigorszky, I., F. Vasas \& G. Borics, 1999. Vízi Természet- és Környezetvédelem, 8, A páncélos-ostoros algák (Dinophyta) kishatározója. Budapest.

Javornický, P., 2003. Taxonomic notes on some freshwater planktonic Cryptophyceae based on light microscopy. Hydrobiologia 502: 271-283.

Kadlubowska, J. Z., 1984. Süßwasserflora von Mitteleuropa, Volume 16: Conjugatophyceae I., Zygnemales. Gustav Fischer Verlag, Jena.

Kelly, M. 2012. The semiotics of slime: visual representation of phytobenthos as an aid to understanding ecological status. Freshwater Reviews 5: 105-119.

Kókai, Zs., I. Bácsi, P. Török, K. Buczkó, E. T-Krasznai, Cs. Balogh, B. Tóthmérész \& V. BBéres, 2015. Halophilic diatom taxa are sensitively indicating even the short term changes in lowland lotic systems. Acta Botanica Croatica 74: 287-302.

Komárek, J. \& K. Anagnostidis, 1998. Süßwasserflora von Mitteleuropa, Volume 19/1: Cyanoprokaryota, 1st part: Chroococcales. Gustav Fischer, Jena, Stuttgart, Lübeck, Ulm.

Komárek, J. \& K. Anagnostidis, 2005. Süßwasserflora von Mitteleuropa, Volume 19/2: Cyanoprokaryota, 2nd part: Oscillatoriales. Elsevier GmbH, München.

Lange, K., C. R. Townsend \& C. D. Matthaei, 2016. A trait based framework for stream algal communities. Ecology and Evolution 6: 23-36. 
Law, R. J., J. A. Elliott \& S. J. Thackeray, 2014. Do functional or morphological classifications explain stream phytobenthic community assemblages? Diatom Research 29: $309-324$.

Lengyel, E., J. Padisák \& Cs. Stenger-Kovács, 2015. Establishment of equilibrium states and effect of disturbances on benthic diatom assemblages of the Torna-stream, Hungary. Hydrobiologia 750: 43-56.

Marcel, R., V. Berthon, V. Castets, F. Rimet, A. Thiers, F. Labat \& B. Fontan, 2017. Modelling diatom life forms and ecological guilds for river biomonitoring. Knowledge and Management of Aquatic Ecosystems 418:1.

MSZ 1484-13:2009, 2009. Water quality. Part 13: Determination of nitrate and nitrite content by spectrophotometric method.

MSZ EN ISO 6878:2004, 2004. Water quality. Determination of phosphorus. Ammonium molybdate spectrometric method (ISO 6878:2004).

MSZ ISO 7150-1:1992, 1992. Water quality. Determination of ammonium. Part 1: Manual spectrophotometric method.

Németh, J., 1997. Vízi Természet- és Környezetvédelem, 3, Az ostoros algák kishatározója 1. (Euglenophyta). Budapest.

Németh, J., 1997. Vízi Természet- és Környezetvédelem, 4, Az ostoros algák kishatározója 2.(Euglenophyta). Budapest.

Padisák, J., L. O. Crossetti \& L. Naselli-Flores, 2009. Use and misuse in the application of the phytoplankton functional classification: a critical review with updates. Hydrobiologia 621: 1-19.

Papp, M., 2010. A növényi sejt. Kossuth Egyetemi Kiadó, Debrecen. (in Hungarian).

Passy, S. I., 2007. Diatom ecological guilds display distinct and predictable behavior along nutrient and disturbance gradients in running waters. Aquatic Botany 86: 171-178. 
Passy S. I. \& C. A. Larson, 2011. Succession in stream biofilms is an environmentally driven gradient of stress tolerance. Microbial Ecology 62: 414-424.

Plenkovic-Moraj, A., K. Koraljka \& M. Gligora, 2008. Effect of current velocity on diatom colonization on glass slides in unpolluted headwater creek. Periodicum Biologorum 110: 291-293.

Rimet, F. \& A. Bouchez, 2012. Life-forms, cell-sizes and ecological guilds of diatoms in European rivers. Knowledge and Management of Aquatic Ecosystems 406:01.

Round, F. E., R. M. Crawford \& D. G. Mann, 1990. The diatoms, Biology, morphology of the genera. Cambridge University Press. 747 pp.

Schmidt, A. \& G. Fehér, 1998. Vízi Természet- és Környezetvédelem, 5, A zöldalgák Chlorococcales rendjének kishatározója 1. Budapest.

Schmidt, A. \& G. Fehér, 1999. Vízi Természet- és Környezetvédelem, 10, A zöldalgák Chlorococcales rendjének kishatározója 2. Budapest.

Schmidt, A. \& G. Fehér, 2001. Vízi Természet- és Környezetvédelem, 13, A sárgászöld algák (Xanthophyceae) kishatározója. Budapest.

Stenger-Kovács, Cs., E. Lengyel, L. O. Crossetti, V. Üveges \& J. Padisák, 2013. Diatom ecological guilds as indicators of temporally changing stressors and disturbances in the small Torna-stream, Hungary. Ecological Indicators 24: 138-147.

Tapolczai, K., A. Bouchez, Cs. Stenger-Kovács, J. Padisák \& F. Rimet, 2016. Trait-based ecological classifications for benthic algae: review and perspectives. Hydrobiologia 776: $1-17$.

Ter Braak, C. J. F. \& P. Šmilauer, 2002. CANOCO reference manual and CanoDraw for Windows user's guide: software for canonical community ordination (version 5). Ithaca, NY: Microcomputer Power. http://www.canoco.com. Accessed 2013. 
Uherkovich, G., É. Ács \& A. Schmidt, 1995. The green algal genera Scenedesmus

(Chlorococcales, Chlorophyceae) with special attention to taxa occurring in Hungary.

Magyar Algológiai Társaság, Budapest.

web1: http://ec.europa.eu/environment/water/participation/map_mc/countries/hungary_en.htm 


\section{Captions}

Table 1 Applying functional traits and their categories.

Type of functional traits

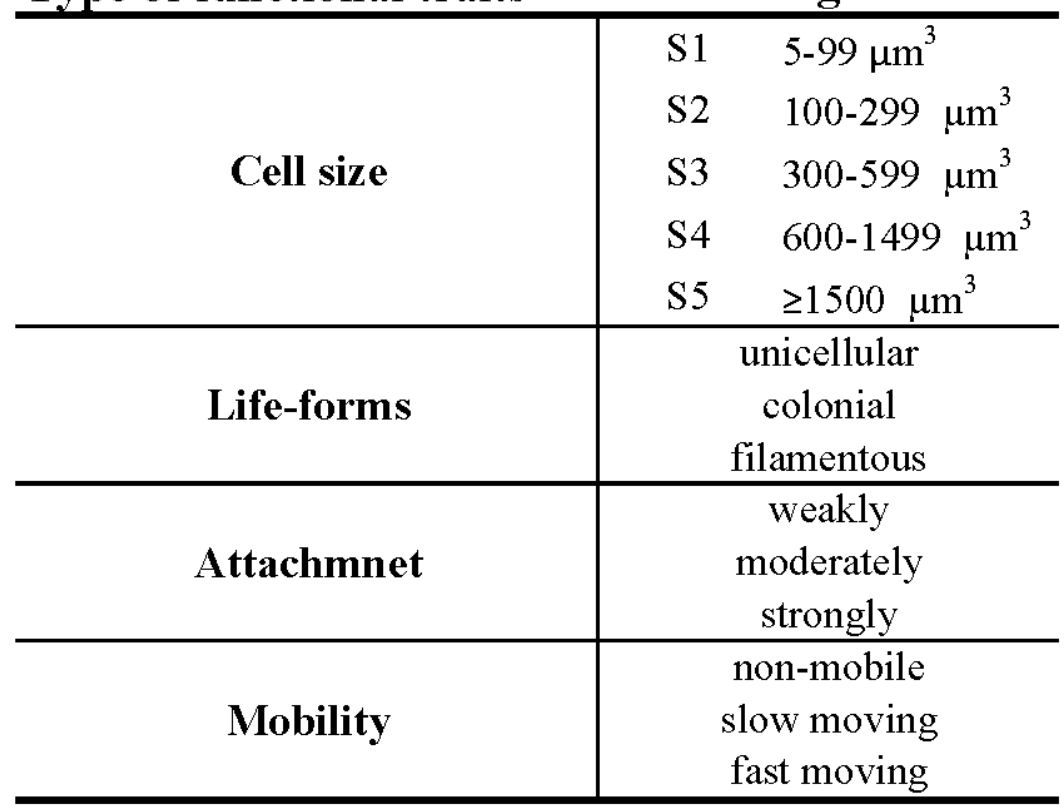


Table 2 Newly created CTGs. The abbreviation indicates the followings: S1-S5 - the cell size categories; SM, FM and NM - the type of mobility (slow moving, fast moving and nonmobile); U, C and F - the type of life-forms (unicellular, colonial and filamentous); Wa, Ma and $\mathrm{Sa}$ - type of attachment (weakly, moderately and strongly attached); n.e. - not existing

\section{CTGs.}

\begin{tabular}{|c|c|c|c|c|c|}
\hline \multirow{2}{*}{\multicolumn{3}{|c|}{ Achived traits in combined groups }} & \multicolumn{3}{|c|}{ life forms } \\
\hline & & & unicellular & colonial & filamentous \\
\hline cell size & mobility & attachment & & CTGs & \\
\hline \multirow{3}{*}{$\mathrm{S} 1$} & non-mobile & $\begin{array}{c}\text { weakly } \\
\text { moderately } \\
\text { strongly } \\
\end{array}$ & $\begin{array}{l}\text { S1_NMUWa } \\
\text { S1_NMUMa } \\
\text { S1_NMUSa }\end{array}$ & $\begin{array}{c}\text { S1_NMCWa } \\
\text { S1_NMCMa } \\
\text { n.e. }\end{array}$ & $\begin{array}{c}\text { S1_NMFWa } \\
\text { S1_NMFMa } \\
\text { n.e. }\end{array}$ \\
\hline & slow moving & $\begin{array}{c}\text { weakly } \\
\text { moderately } \\
\text { strongly }\end{array}$ & $\begin{array}{l}\text { S1_SMUWa } \\
\text { S1_SMUMa } \\
\text { S1_SMUSa }\end{array}$ & $\begin{array}{c}\text { S1_SMCWa } \\
\text { S1_SMCMa } \\
\text { n.e. }\end{array}$ & $\begin{array}{l}\text { n.e. } \\
\text { n.e. } \\
\text { n.e. }\end{array}$ \\
\hline & fast moving & $\begin{array}{c}\text { weakly } \\
\text { moderately } \\
\text { strongly }\end{array}$ & $\begin{array}{c}\text { S1_FMUWa } \\
\text { n.e. } \\
\text { n.e. }\end{array}$ & $\begin{array}{c}\text { S1_FMCWa } \\
\text { n.e. } \\
\text { n.e. }\end{array}$ & $\begin{array}{l}\text { n.e. } \\
\text { n.e. } \\
\text { n.e. } \\
\end{array}$ \\
\hline \multirow{3}{*}{$\mathrm{S} 2$} & non-mobile & $\begin{array}{c}\text { weakly } \\
\text { moderately } \\
\text { strongly }\end{array}$ & $\begin{array}{l}\text { S2_NMUWa } \\
\text { S2_NMUMa } \\
\text { S2_NMUSa }\end{array}$ & $\begin{array}{c}\text { S2_NMCWa } \\
\text { S2_NMCMa } \\
\text { n.e. }\end{array}$ & $\begin{array}{c}\text { S2_NMFWa } \\
\text { S2_NMFMa } \\
\text { n.e. }\end{array}$ \\
\hline & slow moving & $\begin{array}{c}\text { weakly } \\
\text { moderately } \\
\text { strongly }\end{array}$ & $\begin{array}{l}\text { S2_SMUWa } \\
\text { S2_SMUMa } \\
\text { S2_SMUSa }\end{array}$ & $\begin{array}{c}\text { S2_SMCWa } \\
\text { S2_SMCMa } \\
\text { n.e. }\end{array}$ & $\begin{array}{l}\text { n.e. } \\
\text { n.e. } \\
\text { n.e. }\end{array}$ \\
\hline & fast moving & $\begin{array}{c}\text { weakly } \\
\text { moderately } \\
\text { strongly }\end{array}$ & $\begin{array}{c}\text { S2_FMUWa } \\
\text { n.e. } \\
\text { n.e. }\end{array}$ & $\begin{array}{c}\text { S2_FMCWa } \\
\text { n.e. } \\
\text { n.e. }\end{array}$ & $\begin{array}{l}\text { n.e. } \\
\text { n.e. } \\
\text { n.e. } \\
\end{array}$ \\
\hline \multirow{3}{*}{ S3 } & non-mobile & $\begin{array}{c}\text { weakly } \\
\text { moderately } \\
\text { strongly }\end{array}$ & $\begin{array}{l}\text { S3_NMUWa } \\
\text { S3_NMUMa } \\
\text { S3_NMUSa }\end{array}$ & $\begin{array}{c}\text { S3_NMCWa } \\
\text { S3_NMCMa } \\
\text { n.e. }\end{array}$ & $\begin{array}{c}\text { S3_NMFWa } \\
\text { S3_NMFMa } \\
\text { n.e. }\end{array}$ \\
\hline & slow moving & $\begin{array}{c}\text { weakly } \\
\text { moderately } \\
\text { strongly }\end{array}$ & $\begin{array}{l}\text { S3_SMUWa } \\
\text { S3_SMUMa } \\
\text { S3_SMUSa }\end{array}$ & $\begin{array}{c}\text { S3_SMCWa } \\
\text { S3_SMCMa } \\
\text { n.e. }\end{array}$ & $\begin{array}{l}\text { n.e. } \\
\text { n.e. } \\
\text { n.e. }\end{array}$ \\
\hline & fast moving & $\begin{array}{c}\text { weakly } \\
\text { moderately } \\
\text { strongly }\end{array}$ & $\begin{array}{c}\text { S3_FMUWa } \\
\text { n.e. } \\
\text { n.e. }\end{array}$ & $\begin{array}{c}\text { S3_FMCWa } \\
\text { n.e. } \\
\text { n.e. }\end{array}$ & $\begin{array}{l}\text { n.e. } \\
\text { n.e. } \\
\text { n.e. } \\
\end{array}$ \\
\hline \multirow{3}{*}{ S4 } & non-mobile & $\begin{array}{c}\text { weakly } \\
\text { moderately } \\
\text { strongly }\end{array}$ & $\begin{array}{l}\text { S4_NMUWa } \\
\text { S4_NMUMa } \\
\text { S4_NMUSa }\end{array}$ & $\begin{array}{c}\text { S4_NMCWa } \\
\text { S4_NMCMa } \\
\text { n.e. }\end{array}$ & $\begin{array}{c}\text { S4_NMFWa } \\
\text { S4_NMFMa } \\
\text { n.e. }\end{array}$ \\
\hline & slow moving & $\begin{array}{c}\text { weakly } \\
\text { moderately } \\
\text { strongly }\end{array}$ & $\begin{array}{l}\text { S4_SMUWa } \\
\text { S4_SMUMa } \\
\text { S4_SMUSa } \\
\end{array}$ & $\begin{array}{c}\text { S4_SMCWa } \\
\text { S4_SMCMa } \\
\text { n.e. }\end{array}$ & $\begin{array}{l}\text { n.e. } \\
\text { n.e. } \\
\text { n.e. } \\
\end{array}$ \\
\hline & fast moving & $\begin{array}{c}\text { weakly } \\
\text { moderately } \\
\text { strongly }\end{array}$ & $\begin{array}{c}\text { S4_FMUWa } \\
\text { n.e. } \\
\text { n.e. }\end{array}$ & $\begin{array}{c}\text { S4_FMCWa } \\
\text { n.e. } \\
\text { n.e. }\end{array}$ & $\begin{array}{l}\text { n.e. } \\
\text { n.e. } \\
\text { n.e. } \\
\end{array}$ \\
\hline \multirow{3}{*}{ S5 } & non-mobile & $\begin{array}{c}\text { weakly } \\
\text { moderately } \\
\text { strongly }\end{array}$ & $\begin{array}{l}\text { S5_NMUWa } \\
\text { S5_NMUMa } \\
\text { S5_NMUSa }\end{array}$ & $\begin{array}{c}\text { S5_NMCWa } \\
\text { S5_NMCMa } \\
\text { n.e. }\end{array}$ & $\begin{array}{c}\text { S5_NMFWa } \\
\text { S5_NMFMa } \\
\text { n.e. }\end{array}$ \\
\hline & slow moving & $\begin{array}{c}\text { weakly } \\
\text { moderately } \\
\text { strongly }\end{array}$ & $\begin{array}{l}\text { S5_SMUWa } \\
\text { S5_SMUMa } \\
\text { S5_SMUSa } \\
\end{array}$ & $\begin{array}{c}\text { S5_SMCWa } \\
\text { S5_SMCMa } \\
\text { n.e. }\end{array}$ & $\begin{array}{c}\text { n.e. } \\
\text { n.e. } \\
\text { n.e. } \\
\end{array}$ \\
\hline & fast moving & $\begin{array}{c}\text { weakly } \\
\text { moderately } \\
\text { strongly }\end{array}$ & $\begin{array}{c}\text { S5_FMUWa } \\
\text { n.e. } \\
\text { n.e. }\end{array}$ & $\begin{array}{c}\text { S5_FMCWa } \\
\text { n.e. } \\
\text { n.e. }\end{array}$ & $\begin{array}{l}\text { n.e. } \\
\text { n.e. } \\
\text { n.e. }\end{array}$ \\
\hline
\end{tabular}


Table 3 Summary Tables of RDA analyzed the relation between the environmental variables and (a) STGs, and (b) CTGs. The abbreviation indicates the followings: S1-S5 - the cell size categories; SM, FM and NM - the type of mobility (slow moving, fast moving and nonmobile); U, C and F - the type of life-forms (unicellular, colonial and filamentous); Wa, Ma and $\mathrm{Sa}$ - type of attachment (weakly, moderately and strongly attached).

\begin{tabular}{|c|c|c|c|c|c|c|}
\hline \multicolumn{7}{|c|}{ A.) Relation between STGs and the environmental variables } \\
\hline \multicolumn{7}{|c|}{ Method: RDA } \\
\hline \multicolumn{7}{|c|}{$\begin{array}{l}\text { Total variation is } 434.00000 \text {, explanatory variables account for } 77.8 \% \\
\text { adjusted explained variation is } 72.2 \%\end{array}$} \\
\hline \multicolumn{7}{|c|}{ Summary Table: } \\
\hline Statistic & Axis 1 & Axis 2 & Axis 3 & Axis 4 & Axis 5 & Axis 6 \\
\hline Eigenvalues & 0.6248 & 0.1394 & 0.0072 & 20.0054 & 0.0007 & 0.0002 \\
\hline Explained variation & 62.48 & 13.94 & 0.72 & 0.54 & 0.07 & 0.02 \\
\hline Pseudo-canonical correlation & 0.9586 & 0.8352 & 0.4511 & 0.3746 & 0.3668 & 0.1485 \\
\hline Explained fitted variation (cumulative) & 80.34 & 98.27 & 99.19 & 99.87 & 99.97 & 100 \\
\hline \multicolumn{7}{|l|}{ Correlation matrix } \\
\hline & Axis 1 & Axis 2 & Axis 3 & Axis 4 & Axis 5 & Axis 6 \\
\hline S1 & 0.9666 & -0.1198 & -0.0042 & $2-0.0462$ & -0.0456 & -0.007 \\
\hline $\mathrm{S} 2$ & -0.7537 & -0.4612 & -0.1196 & -0.067 & 0.0137 & 0.0042 \\
\hline S3 & 0.3813 & -0.046 & 0.0503 & 0.203 & -0.0181 & 0.0114 \\
\hline $\mathrm{S} 4$ & -0.8232 & -0.0118 & -0.0728 & 0.1385 & 0.0435 & -0.0268 \\
\hline S5 & -0.6758 & 0.5346 & 0.1011 & -0.066 & 0.0451 & 0.0149 \\
\hline SM & 0.8877 & -0.2675 & 0.0365 & 0.0063 & 0.0124 & -0.006 \\
\hline $\mathrm{FM}$ & 0.0336 & 0.8031 & -0.0676 & 0.0072 & -0.0086 & 0.0082 \\
\hline NM & -0.9226 & -0.233 & 0.0054 & -0.0109 & -0.0072 & 0.001 \\
\hline $\mathrm{U}$ & 0.9123 & 0.2457 & 0.0215 & 0.0091 & 0.0208 & 0.0032 \\
\hline C & -0.8664 & -0.319 & -0.0818 & -0.0032 & -0.0194 & 0.0058 \\
\hline $\mathrm{F}$ & -0.9132 & 0.0475 & 0.1889 & -0.0276 & -0.022 & -0.0337 \\
\hline Wa & -0.5691 & 0.5849 & -0.0865 & 0.0088 & -0.0337 & -0.0097 \\
\hline Ma & -0.8921 & -0.2867 & 0.107 & 0.0407 & -0.0096 & 0.0301 \\
\hline $\mathrm{Sa}$ & 0.8881 & -0.2784 & 0.0072 & -0.0279 & 0.0299 & -0.0087 \\
\hline \multicolumn{7}{|c|}{ B.) Relation between CTGs and the environmental variables } \\
\hline \multirow{2}{*}{\multicolumn{7}{|c|}{$\begin{array}{l}\text { Method: RDA } \\
\text { Total variation is } 1037.534 \text {, explanatory variables account for } 53.3 \% \\
\text { adjusted explained variation is } 41.6 \%\end{array}$}} \\
\hline & & & & & & \\
\hline \multicolumn{7}{|c|}{ Summary Table: } \\
\hline Statistic & Axis 1 & Axis 2 & Axis 3 & Axis 4 & Axis 5 & Axis 6 \\
\hline Eigenvalues & 0.3691 & 0.0581 & 0.0524 & 0.0305 & 0.0157 & 0.0068 \\
\hline Explained variation & 36.91 & 5.81 & 5.24 & 3.05 & 1.57 & 0.68 \\
\hline Pseudo-canonical correlation & 0.9688 & 0.8735 & 0.7344 & 0.7021 & 0.5963 & 0.519 \\
\hline Explained fitted variation (cumulative) & 69.3 & 80.2 & 90.04 & 95.77 & 98.71 & 100 \\
\hline \multicolumn{7}{|l|}{ Correlation matrix } \\
\hline & Axis 1 & Axis 2 & Axis 3 & Axis 4 & Axis 5 & Axis 6 \\
\hline S1_FMUWa & 0.7927 & 0.345 & -0.1485 & $\quad 0.212$ & $\quad 0.133$ & -0.0647 \\
\hline S1_NMCWa & 0.1666 & 0.0734 & 0.0406 & -0.131 & 0.0166 & 0.0293 \\
\hline S1_NMFWa & 0.2001 & 0.2444 & -0.0755 & -0.0138 & 0.1214 & -0.1688 \\
\hline S1_NMUWa & -0.2572 & -0.4719 & 0.1953 & 0.329 & 0.0617 & -0.0803 \\
\hline Sl_NMUMa & 0.6471 & -0.0365 & -0.0458 & -0.0595 & -0.0187 & 0.0287 \\
\hline S1_SMUSa & 0.9071 & -0.2087 & 0.0433 & 0.0191 & 0.0557 & -0.0555 \\
\hline S2_FMUWa & -0.1078 & -0.7389 & 0.0131 & -0.2865 & -0.1087 & -0.0299 \\
\hline S2_NMCWa & -0.8731 & -0.2581 & -0.01 & -0.027 & 0.1153 & -0.0465 \\
\hline S2_NMFWa & -0.1346 & 0.1386 & 0.218 & 0.2276 & -0.426 & 0.0047 \\
\hline S2_NMUWa & -0.2341 & -0.0923 & 0.4532 & -0.1719 & 0.0578 & 0.0758 \\
\hline S3_FMCWa & -0.1561 & -0.1074 & -0.0804 & -0.0667 & 0.0522 & 0.0078 \\
\hline S3_FMUWa & 0.4798 & -0.0765 & 0.1278 & 0.0862 & 0.1609 & -0.0465 \\
\hline S3_NMCWa & 0.5727 & -0.0511 & -0.3445 & -0.1484 & -0.0763 & 0.0421 \\
\hline S3_NMFMa & -0.4826 & -0.1214 & -0.2934 & 0.0706 & -0.0731 & 0.0914 \\
\hline S3_SMCWa & -0.1791 & -0.0385 & 0.6089 & -0.1192 & -0.0226 & 0.1041 \\
\hline S3_SMCMa & 0.3555 & 0.0546 & -0.0422 & -0.2166 & -0.1127 & -0.4093 \\
\hline S3_SMUSa & 0.1954 & -0.0012 & 0.0374 & 0.2426 & 0.1045 & -0.0802 \\
\hline S3_SMUMa & 0.3978 & 0.107 & 0.4698 & 0.0221 & 0.0279 & 0.0626 \\
\hline S4_FMUWa & -0.3285 & 0.1717 & -0.1673 & 0.4624 & 0.1483 & 0.0838 \\
\hline S4_NMCMa & -0.9611 & 0.1254 & 0.0433 & 0.0184 & 0.1111 & -0.0457 \\
\hline S4_NMUWa & 0.0381 & -0.3716 & 0.169 & 0.155 & 0.0112 & -0.0194 \\
\hline S4_SMCWa & 0.6804 & 0.0782 & -0.2867 & 0.2559 & 0.063 & -0.0251 \\
\hline S5_FMUWa & -0.8407 & 0.4428 & -0.0717 & 0.0307 & 0.0449 & 0.011 \\
\hline S5_NMCWa & 0.0836 & 0.0384 & 0.3233 & 0.1476 & 0.1694 & -0.0526 \\
\hline S5_NMCMa & -0.5146 & 0.1709 & -0.389 & 0.0881 & -0.0716 & -0.1578 \\
\hline S5_NMFWa & -0.7381 & 0.5214 & 0.148 & -0.1004 & -0.0014 & -0.0032 \\
\hline S5_NMFMa & -0.8918 & -0.2259 & -0.1619 & -0.0891 & -0.0227 & 0.0008 \\
\hline S5_SMCWa & 0.3967 & -0.019 & -0.2568 & 0.1523 & 0.1019 & 0.0152 \\
\hline S5_SMCMa & -0.1203 & 0.2614 & 0.5549 & -0.2643 & 0.0832 & 0.0091 \\
\hline S5 SMUSa & 0.0524 & 0.0432 & 0.1624 & -0.2301 & 0.1268 & 0.0061 \\
\hline
\end{tabular}


Table 4 Ecologically important differences between STGs and CTGs analyses. The abbreviation indicates the followings: S1-S5 - the cell size categories; SM, FM and NM - the type of mobility (slow moving, fast moving and non-mobile); U, C and F - the type of lifeforms (unicellular, colonial and filamentous); Wa, $\mathrm{Ma}$ and $\mathrm{Sa}$ - type of attachment (weakly, moderately and strongly attached); pos - indicating positive correlations; neg - indicating negative correlations.

\begin{tabular}{|c|c|}
\hline CTGs or STGs & correlation type \\
\hline \multirow[t]{3}{*}{ S3SMCMa } & time - pos \\
\hline & nitrate - neg \\
\hline & vs \\
\hline colonial & nitrate - pos \\
\hline moderately attached & nitrate - pos \\
\hline \multirow[t]{2}{*}{ S4NMCMa } & WD, WV - pos \\
\hline & vs \\
\hline non-mobile & nitrate - pos \\
\hline colonial & nitrate - pos \\
\hline moderately attached & nitrate - pos \\
\hline \multirow[t]{2}{*}{ S5NMCMa } & WD, WV - pos \\
\hline & vs \\
\hline non-mobile & nitrate - pos \\
\hline colonial & nitrate - pos \\
\hline moderately attached & nitrate - pos \\
\hline \multirow[t]{4}{*}{ S3NMFMa } & nitrate - pos \\
\hline & WD, WV - pos \\
\hline & time - neg \\
\hline & vs \\
\hline S3 & time - pos \\
\hline \multirow[t]{2}{*}{ S4FMUWa } & $\begin{array}{l}\text { WD, WV - pos } \\
\text { time - neg }\end{array}$ \\
\hline & vs \\
\hline fast moving & nutrients - neg \\
\hline \multirow[t]{2}{*}{ S5FMUWa } & $\begin{array}{l}\text { WD, WV - pos } \\
\text { time - neg }\end{array}$ \\
\hline & vs \\
\hline fast moving & nutrients - neg \\
\hline \multirow[t]{2}{*}{ S2FMUWa } & nitrate - pos \\
\hline & vs \\
\hline fast moving & nutrients - neg \\
\hline \multirow[t]{2}{*}{ S3FMUWa } & phosphate - pos \\
\hline & vs \\
\hline fast moving & nutrients - neg \\
\hline
\end{tabular}


Fig. 1 (a) Daily data of precipitation $(\mathrm{mm})$ provided by the National Meteorological Sevice.

Black diamonds indicate the dates of diatom sampling; (b) Changes in water depth (cm; black diamond) and water velocity $\left(\mathrm{ms}^{-1}\right.$; black square) during the study period.
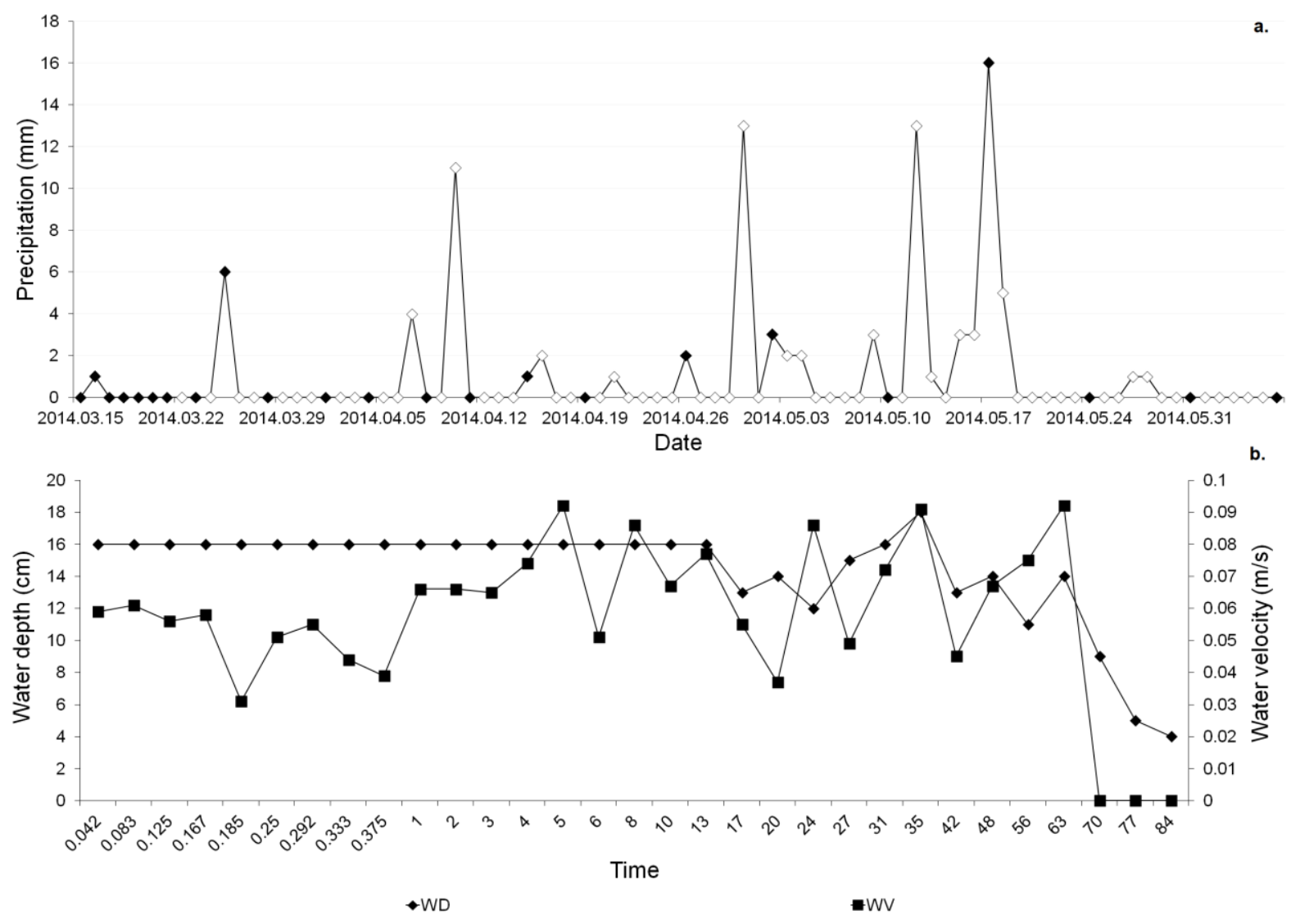
Fig. 2 Relation of STGs and the environmental variables displayed by RDA based on single trait' abundances. The explained variations were $62.48 \%$ and $13.95 \%$ for the first and second axes. For abbreviations see Table 2.

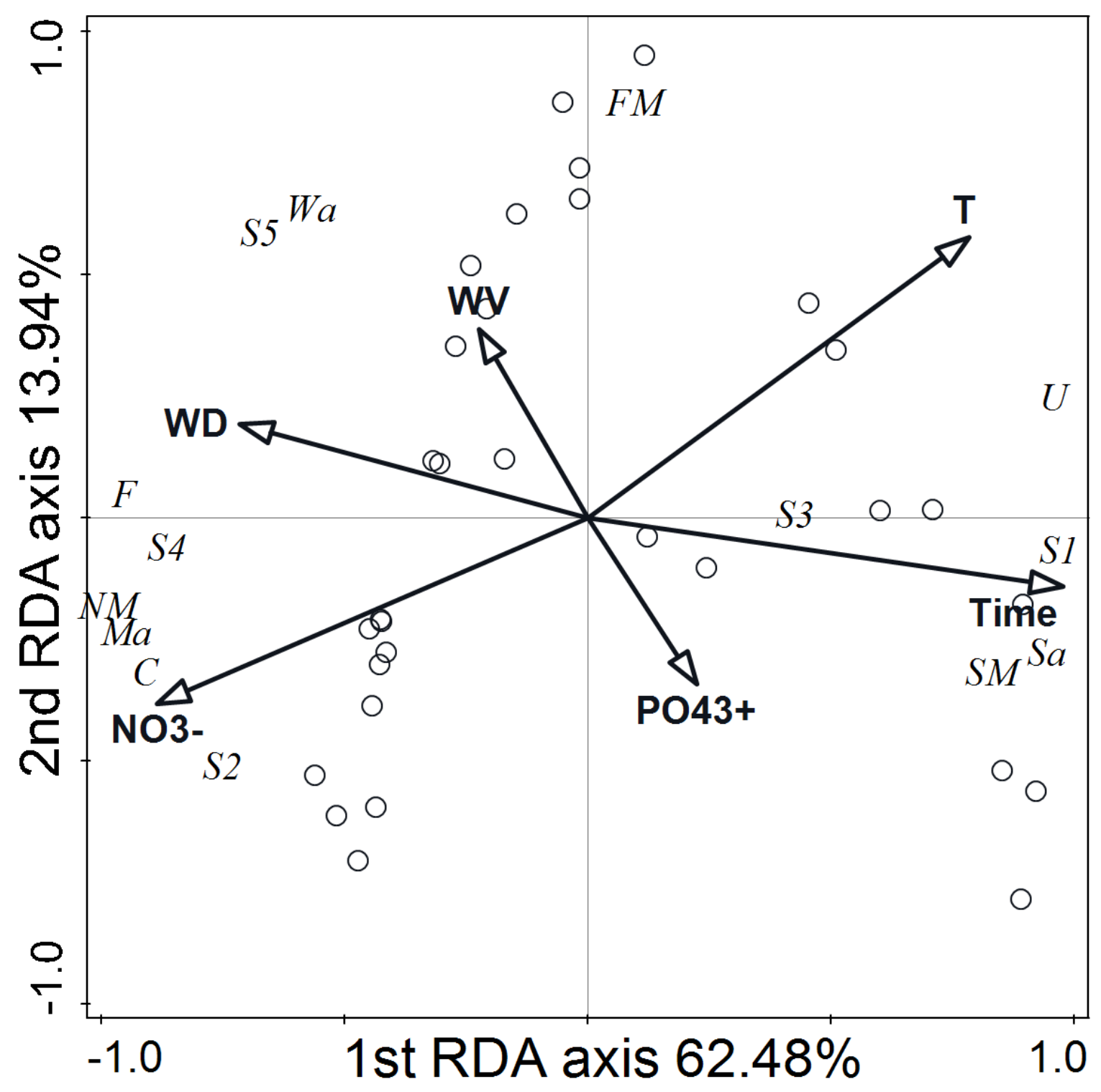


Fig. 3 Relation of CTGs and the environmental variables displayed by RDA based on combined groups' abundances. The explained variations were $36.92 \%$ and $5.81 \%$ for the first and second axes. For abbreviations see Table 2.

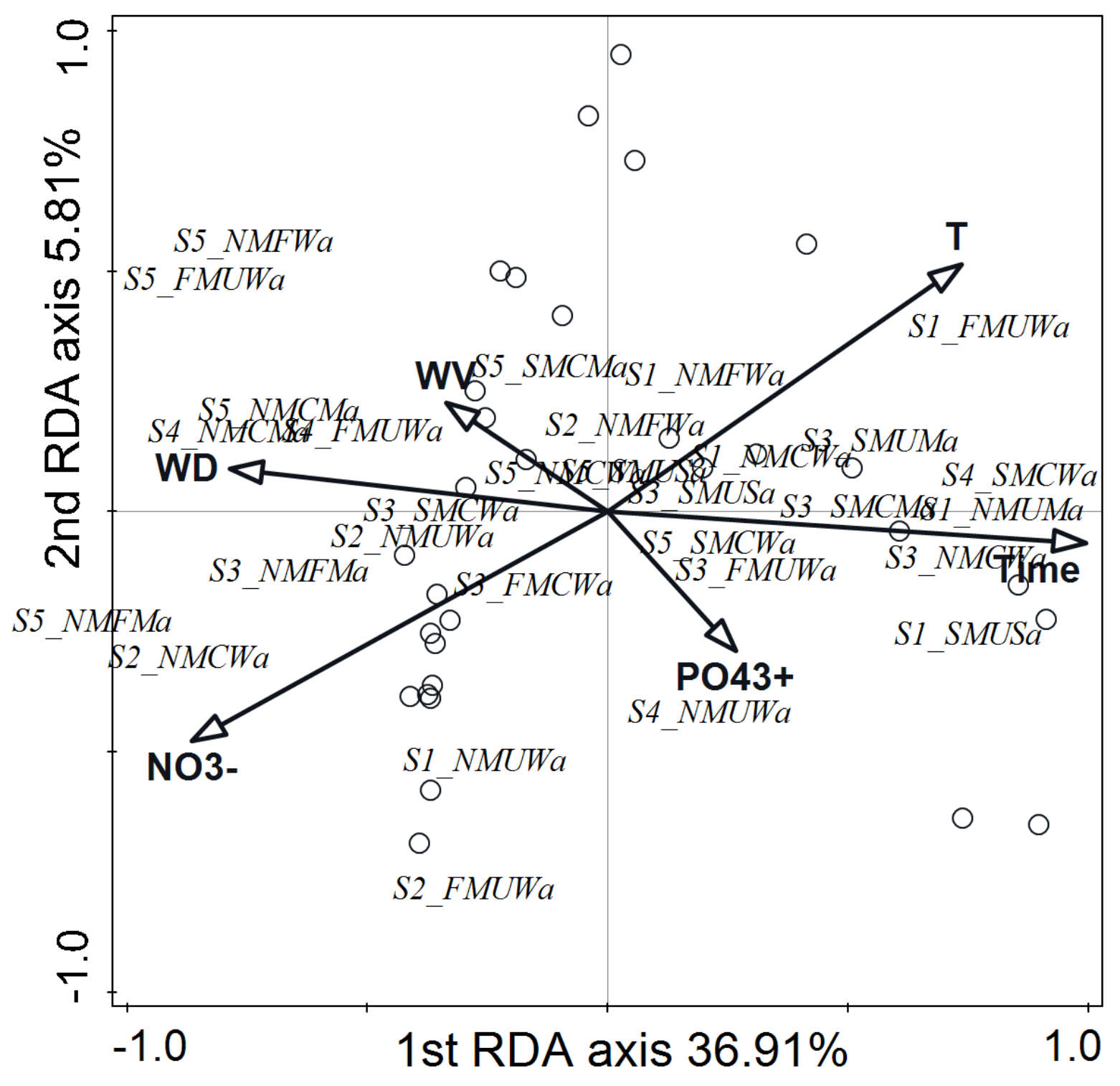


Appendix 1 Summary of the data set for the 12 tested chemical and physical parameters:

conductivity (COND $\left.-\mu \mathrm{S} \mathrm{m}^{-1}\right)$, oxidation-reduction potential $(\mathrm{ORP}-\mathrm{mV}), \mathrm{pH}$, dissolved oxygen concentration ( $\left.\mathrm{DO}-\mathrm{mg} \mathrm{L}^{-1}\right)$, oxygen saturation $(\mathrm{OS}-\%)$, water temperature $\left(\mathrm{T},{ }^{\circ} \mathrm{C}\right)$, water depth $(\mathrm{WD}, \mathrm{cm})$, water velocity $\left(\mathrm{WV}-\mathrm{m} \mathrm{s}^{-1}\right)$, nitrite $\left(\mathrm{NO}_{2}{ }^{-}-\mathrm{mg} \mathrm{L}^{-1}\right)$, nitrate $\left(\mathrm{NO}_{3}{ }^{-}-\right.$ $\left.\mathrm{mg} \mathrm{L}{ }^{-1}\right)$, ammonium $\left(\mathrm{NH}_{4}^{+}-\mathrm{mg} \mathrm{L}^{-1}\right)$ and soluble reactive phosphorus $\left(\mathrm{PO}_{4}{ }^{3-} \mathrm{mg} \mathrm{L}^{-1}\right)$.

\begin{tabular}{|c|c|c|c|c|c|c|c|c|c|c|c|c|}
\hline & $\begin{array}{l}\text { COND } \\
861323\end{array}$ & $\begin{array}{l}\text { ORP } \\
212671\end{array}$ & pH & $\begin{array}{l}\text { DO } \\
7894\end{array}$ & OS & $\begin{array}{l}\mathbf{T} \\
12468\end{array}$ & $\begin{array}{l}\text { WD } \\
14387\end{array}$ & $\begin{array}{l}\text { WV } \\
0.057\end{array}$ & NO2- & NO3- & NH4+ & $\begin{array}{l}\text { PO43- } \\
0.601\end{array}$ \\
\hline rd deviation & 31.163 & 69.394 & 0.188 & 1.852 & 15.694 & 4.199 & 3.211 & 0.025 & 0.009 & 1.893 & 0.090 & 0.621 \\
\hline
\end{tabular}


Appendix 2 List 68 taxa found in the samples, and their assignment to cell size, life form, attachment and mobility categories, and CTGs.

\begin{tabular}{|c|c|c|c|c|c|c|c|c|c|c|c|c|c|c|c|}
\hline & S1 & & & & & SM & FM & & & & & & & & CTGs \\
\hline Planothidium lanceolatum & 0 & 0 & 1 & 0 & 0 & 1 & 0 & 0 & 10 & 00 & 0 & 0 & 0 & 1 & S3_SMUSa \\
\hline Achnanthidium minutissimum & 1 & 0 & 0 & 0 & 0 & 1 & 0 & 0 & 10 & 0 & 0 & 0 & 0 & 1 & S1_SMUSa \\
\hline Actinastrum hantzschii & 0 & 1 & 0 & 0 & 0 & 0 & 0 & 1 & 01 & 1 & 0 & 1 & 0 & 0 & S2_NMCWa \\
\hline Amphora pediculus & 1 & 0 & 0 & 0 & 0 & 1 & 0 & 0 & 10 & 00 & 0 & 0 & 0 & 1 & S1_SMUSa \\
\hline Amphora sp. & 0 & 0 & 0 & 0 & 1 & 1 & 0 & 0 & 10 & 00 & 0 & 0 & 0 & 1 & S5_SMUSa \\
\hline Anabaena sp. & 0 & 0 & 0 & 0 & 1 & 0 & 0 & 1 & 00 & 0 & 1 & 1 & 0 & 0 & S5_NMFWa \\
\hline Anomoeoneis sphaerophora & 0 & 0 & 0 & 0 & 1 & 0 & 1 & 0 & 10 & 0 & 0 & 1 & 0 & 0 & S5_FMUWa \\
\hline Aphanocapsa sp. & 1 & 0 & 0 & 0 & 0 & 0 & 0 & 1 & 01 & 1 & 0 & 1 & 0 & 0 & S1_NMCWa \\
\hline Aphanothece sp. & 1 & 0 & 0 & 0 & 0 & 0 & 0 & 1 & 01 & 1 & 0 & 1 & 0 & 0 & S1_NMCWa \\
\hline Aulacoseira granulata & 0 & 0 & 0 & 0 & 1 & 0 & 0 & 1 & 00 & 0 & 1 & 1 & 0 & 0 & S5_NMFWa \\
\hline Caloneis sp. & 0 & 0 & 1 & 0 & 0 & 0 & 1 & 0 & 10 & 0 & 0 & 1 & 0 & 0 & S3_FMUWa \\
\hline Centralessp. & 0 & 0 & 0 & 1 & 0 & 0 & 0 & 1 & 10 & 00 & 0 & 1 & 0 & 0 & S4_NMUWa \\
\hline Centritractus belenophorus & 0 & 0 & 0 & 1 & 0 & 0 & 0 & 1 & 10 & 00 & 0 & 1 & 0 & 0 & S4_NMUWa \\
\hline Characium sp. & 1 & 0 & 0 & 0 & 0 & 0 & 0 & 1 & 10 & 0 & 0 & 0 & 1 & 0 & S1_NMUMa \\
\hline Chlamydomonas sp. & 0 & 0 & 0 & 1 & 0 & 0 & 1 & 0 & 10 & 0 & 0 & 1 & 0 & 0 & S4_FMUWa \\
\hline Chlorella sp. & 1 & 0 & 0 & 0 & 0 & 0 & 0 & 1 & 10 & $\begin{array}{lll}0 & 0\end{array}$ & 0 & 1 & 0 & 0 & S1_NMUWa \\
\hline Chroococcus sp. & 0 & 1 & 0 & 0 & 0 & 0 & 0 & 1 & 01 & 10 & 0 & 1 & 0 & 0 & S2_NMCWa \\
\hline Chrysococcus rufescens & 0 & 0 & 1 & 0 & 0 & 0 & 1 & 0 & 1 & 0 & 0 & 1 & 0 & 0 & S3_FMUWa \\
\hline Cocconeis placentula & 0 & 0 & 0 & 0 & 1 & 1 & 0 & 0 & 1 & 0 & 0 & 0 & 0 & 1 & S5_SMUSa \\
\hline Cryptomonas sp. & 0 & 0 & 0 & 1 & 0 & 0 & 1 & 0 & 1 & 0 & 0 & 1 & 0 & 0 & S4_FMUWa \\
\hline Cyclotella meneghiniana & 0 & 0 & 0 & 1 & 0 & 0 & 0 & 1 & 1 & 0 & 0 & 1 & 0 & 0 & S4_NMUWa \\
\hline Cymatopleura solea & 0 & 0 & 0 & 0 & 1 & 0 & 1 & 0 & 1 & 0 & 0 & 1 & 0 & 0 & S5_FMUWa \\
\hline Encyonema sp. & 0 & 0 & 1 & 0 & 0 & 1 & 0 & 0 & 0 & 1 & 0 & 0 & 1 & 0 & S3_SMCMa \\
\hline Diatoma vulgaris & 0 & 0 & 0 & 0 & 1 & 0 & 0 & 1 & 0 & 1 & 0 & 1 & 0 & 0 & S5_NMCWa \\
\hline Epithemia sp. & 0 & 0 & 0 & 0 & 1 & 0 & 1 & 0 & 1 & 0 & 0 & 1 & 0 & 0 & S5_FMUWa \\
\hline Lepocinclis acus & 0 & 0 & 0 & 0 & 1 & 0 & 1 & 0 & 1 & 0 & 0 & 1 & 0 & 0 & S5_FMUWa \\
\hline Euglena sp. & 0 & 0 & 0 & 0 & 1 & 0 & 1 & 0 & 1 & 0 & 0 & 1 & 0 & 0 & S5_FMUWa \\
\hline Lepocinclis spirogyroides & 0 & 0 & 0 & 0 & 1 & 0 & 1 & 0 & 1 & 0 & 0 & 1 & 0 & 0 & S5_FMUWa \\
\hline Euglena texta & 0 & 0 & 0 & 0 & 1 & 0 & 1 & 0 & 1 & 0 & 0 & 1 & 0 & 0 & S5_FMUWa \\
\hline Eunotia bilunaris & 0 & 0 & 0 & 1 & 0 & 1 & 0 & 0 & 0 & 1 & 0 & 1 & 0 & 0 & S4_SMCWa \\
\hline Eunotia formica & 0 & 0 & 0 & 0 & 1 & 1 & 0 & 0 & 0 & 1 & 0 & 1 & 0 & 0 & S5_SMCWa \\
\hline Eunotia sp. & 0 & 0 & 1 & 0 & 0 & 1 & 0 & 0 & 0 & 1 & 0 & 1 & 0 & 0 & S3_SMCWa \\
\hline Fragilaria capucina & 0 & 1 & 0 & 0 & 0 & 0 & 0 & 1 & 0 & 1 & 0 & 1 & 0 & 0 & S2_NMCWa \\
\hline Gomphonema acuminatum & 0 & 0 & 0 & 0 & 1 & 1 & 0 & 0 & 0 & 10 & 0 & 0 & 1 & 0 & S5_SMCMa \\
\hline Gomphonema sp. & 0 & 0 & 1 & 0 & 0 & 1 & 0 & 0 & 1 & 0 & 0 & 0 & 1 & 0 & S3_SMUMa \\
\hline Gymmodinium sp. & 0 & 0 & 0 & 0 & 1 & 0 & 1 & 0 & 1 & 0 & 0 & 1 & 0 & 0 & S5_FMUWa \\
\hline Gyrosigma acuminatum & 0 & 0 & 0 & 0 & 1 & 0 & 1 & 0 & 1 & 0 & 0 & 1 & 0 & 0 & S5_FMUWa \\
\hline Gyrosigma attenuatum & 0 & 0 & 0 & 0 & 1 & 0 & 1 & 0 & 1 & 0 & 0 & 1 & 0 & 0 & S5_FMUWa \\
\hline Klebsomidium sp. & 0 & 0 & 1 & 0 & 0 & 0 & 0 & 1 & 0 & 0 & 1 & 0 & 1 & 0 & S3_NMFMa \\
\hline Limnothrix redekei & 0 & 1 & 0 & 0 & 0 & 0 & 0 & 1 & 0 & 0 & 1 & 1 & 0 & 0 & S2_NMFWa \\
\hline Limnothrix sp. & 0 & 1 & 0 & 0 & 0 & 0 & 0 & 1 & 0 & 0 & 1 & 1 & 0 & 0 & S2_NMFWa \\
\hline Melosira varians & 0 & 0 & 0 & 0 & 1 & 0 & 0 & 1 & 0 & 0 & 1 & 1 & 0 & 0 & S5_NMFWa \\
\hline Meridion circulare & 0 & 0 & 0 & 1 & 0 & 0 & 0 & 1 & 0 & 1 & 0 & 0 & 1 & 0 & S4_NMCMa \\
\hline Monoraphidium contortum & 0 & 1 & 0 & 0 & 0 & 0 & 0 & 1 & 1 & 0 & 0 & 1 & 0 & 0 & S2_NMUWa \\
\hline Monoraphidium griffithii & 0 & 1 & 0 & 0 & 0 & 0 & 0 & 1 & 1 & 0 & 0 & 1 & 0 & 0 & S2_NMUWa \\
\hline Monoraphidium tortile & 0 & 1 & 0 & 0 & 0 & 0 & 0 & 1 & 1 & 0 & 0 & 1 & 0 & 0 & S2_NMUWa \\
\hline Navic & 1 & 0 & 0 & 0 & 0 & 0 & 1 & 0 & 1 & 0 & 0 & 1 & 0 & 0 & S1_FMUWa \\
\hline Nitzschia acicularis & 0 & 1 & 0 & 0 & 0 & 0 & 1 & 0 & 1 & 0 & 0 & 1 & 0 & 0 & S2_FMUWa \\
\hline Nitzschia sp. & 0 & 0 & 1 & 0 & 0 & 0 & 1 & 0 & 1 & 0 & 0 & 1 & 0 & 0 & S3_FMUWa \\
\hline Pandorina morum & 0 & 0 & 1 & 0 & 0 & 0 & 1 & 0 & 0 & 10 & 0 & 1 & 0 & 0 & S3_FMCWa \\
\hline Peridinium sp. & 0 & 0 & 0 & 0 & 1 & 0 & 1 & 0 & 1 & 0 & 0 & 1 & 0 & 0 & S5_FMUWa \\
\hline Pinnularia microstauron & 0 & 0 & 0 & 0 & 1 & 0 & 1 & 0 & 1 & 0 & 0 & 1 & 0 & 0 & S5_FMUWa \\
\hline Pinnularia sp. & 0 & 0 & 0 & 1 & 0 & 0 & 1 & 0 & 1 & 0 & 0 & 1 & 0 & 0 & S4_FMUWa \\
\hline Plagioselmis lacustris & 0 & 0 & 1 & 0 & 0 & 0 & 1 & 0 & 1 & 0 & 0 & 1 & 0 & 0 & S3_FMUWa \\
\hline Plagioselmis nannoplanctice & 0 & 1 & 0 & 0 & 0 & 0 & 1 & 0 & 1 & 0 & 0 & 1 & 0 & 0 & S2_FMUWa \\
\hline Planktolyngbya limnetica & 1 & 0 & 0 & 0 & 0 & 0 & 0 & 1 & 0 & 0 & 1 & 1 & 0 & 0 & S1_NMFWa \\
\hline Pseudanabaena sp. & 0 & 1 & 0 & 0 & 0 & 0 & 0 & 1 & 0 & 0 & 1 & 1 & 0 & 0 & S2_NMFWa \\
\hline Rhoicosphenia abbreviata & 0 & 0 & 1 & 0 & 0 & 0 & 0 & 1 & 0 & 1 & 0 & 1 & 0 & 0 & S3_NMCWa \\
\hline Scenedesmus quadricauda & 0 & 0 & 1 & 0 & 0 & 0 & 0 & 1 & 0 & 1 & 0 & 1 & 0 & 0 & S3_NMCWa \\
\hline Stauroneis sp. & 0 & 0 & 0 & 0 & 1 & 0 & 1 & 0 & 1 & 0 & 0 & 1 & 0 & 0 & S5_FMUWa \\
\hline Surirella brebissonii & 0 & 0 & 0 & 0 & 1 & 0 & 1 & 0 & 1 & 0 & 0 & 1 & 0 & 0 & S5_FMUWa \\
\hline Surirella sp. & 0 & 0 & 0 & 1 & 0 & 0 & 1 & 0 & 1 & 0 & 0 & 1 & 0 & 0 & S4_FMUWa \\
\hline Trachelomonas intermedia & 0 & 0 & 0 & 0 & 1 & 0 & 1 & 0 & 1 & 0 & 0 & 1 & 0 & 0 & S5_FMUWa \\
\hline Trachelomonas volvocina & 0 & 0 & 0 & 0 & 1 & 0 & 1 & 0 & 1 & 0 & 0 & 1 & 0 & 0 & S5_FMUWa \\
\hline Trachelomonas volvocinopsis & 0 & 0 & 0 & 0 & 1 & 0 & 1 & 0 & 1 & 0 & 0 & 1 & 0 & 0 & S5_FMUWa \\
\hline Trachelomonas woycickii & 0 & 0 & 0 & 0 & 1 & 0 & 1 & 0 & 1 & 0 & 0 & 1 & 0 & 0 & S5_FMUWa \\
\hline Ulnaria ulna & 0 & 0 & 0 & 0 & 1 & 0 & 0 & 1 & 0 & 1 & 0 & 0 & 1 & 0 & S5_NMCMa \\
\hline Filamentous green algae & 0 & 0 & 0 & 0 & 1 & 0 & 0 & 1 & 0 & 0 & 1 & 0 & 1 & 0 & S5_NMFMa \\
\hline
\end{tabular}

